\title{
Pohl'ad rodičov na vzdelávanie počas pandémie covid-19 na Slovensku - porovnanie rodičov detí so špeciálnymi potrebami a rodičov detí bez identifikovaných špeciálnych potrieb ${ }^{1}$
}

\author{
Robert Tomšik, Eva Rajčániová, Petra Ferenčíková, \\ Alena Kopányiová
}

Oddelenie diagnostických nástrojov, Výskumný ústav detskej psychológie a patopsychológie VÚDPaP

Redakci zasláno 4. 6. 2020 / upravená verze obdržena 16. 9. 2020 /

k uveřejnění přijato 6. 10. 2020

\begin{abstract}
Abstrakt: Ciel'om empirickej štúdie je mapovat' priebeh dištančného vzdelávania na Slovensku počas pandémie covid-19. Konkrétne, výskum sa zameriava na preskúmanie rozdielov medzi rodičmi detí so špeciálnymi výchovno-vzdelávacími potrebami (ŠVVP) a rodičmi, ktorých deti nemajú identifikované ŠVVP v špecifikách dištančného vzdelávania. Ďalej sa výskum zameriava na zistenie ako zabezpečovanie vzdelávania v domácom prostredí prežívajú rodičia a ich deti - ich obavy a vnímanie podpory zo strany školy. Pomocou dotazníka vlastnej konštrukcie sú tieto premenné zistované na vzorke $\mathrm{N}=462$ rodičov. Prvá čast' štúdie je venovaná teoretickým východiskám a aktuálnym empirickým výskumom, ktoré napíňajú výskumné ciele práce. Ďalšia čast' popisuje metodologické postupy. Posledná čast' príspevku je venovaná interpretácii výsledkov, v ktorej sú bližšie opísané nasledovné zistenia: žiaci 2. stupňa ZŠ a SŠ venujú denne o približne hodinu viacej času učebnej činnosti, v porovnaní so žiakmi 1. stupňa; rodičia, ktorí sa cítia byt' menej kompetentní pri vzdelávaní svojich detí doma, majú tendenciu intenzívnejšie prežívat' obavy, že ich dieta doma nezíska dostatočné vedomosti; najčastejšie obavy rodičov vo vzt’ahu k učivu a iným školským povinnostiam sú zvládnutie školských povinností ich detí, či obavy, že neprebrali dostatok učiva; najčastejšie obavy detí sú späté s absenciou sociálnych kontaktov a obavy z nezvládnutia školských povinností. Medzi rodičmi detí so ŠP a bez ŠP boli zistené rozdiely v plánovaní učebnej činnosti; nedostatku vybraných učebných pomôcok; či potrebe podpory špecialistov a odborníkov.
\end{abstract}

Klúčové slová: covid-19, dištančné vzdelávanie, špeciálne výchovno-vzdelávacie potreby

1 Výskum bol realizovaný v rámci národného projektu NFP312010APV4 - Aktualizácia systému usmerňovania a rozvoja d'alších zložiek $v$ systéme poradenstva a prevencie.

https://doi.org/10.5817/PedOr2020-2-156 


\section{Teoretické východiská}

Pandémia nového koronavírusu (SARS-CoV-2) a choroba covid-19 ním spôsobená mala bezprecedentný dopad na systém školstva po celom svete. Organizácia UNESCO hovorí o vyše jednej miliarde žiakov a študentov, ktorí boli celosvetovo zasiahnutí opatreniami v súvislosti s pandémiou koronavírusu (UNESCO, 2020). Na Slovensku bol prvý prípad ochorenia covid-19 potvrdený dňa 6. marca 2020, na čo vláda SR vydala súbor nariadení, ktoré sa týkali zákazov školských sútaží a predmetových olympiád, exkurzií a výletov, všetkých športových podujatí realizovaných v sústave škôl a školských zariadení. Postupne sa zatvorili tiež detské ihriská, vonkajšie aj vnútorné športoviská, detské kútiky a všetky vol'nočasové zariadenia, kde by dochádzalo k združovaniu detí. Od 16. marca 2020 došlo k úplnému zatvoreniu vzdelávacích inštitúcií a Ministerstvo školstva, vedy, výskumu a športu SR nariadilo do odvolania prerušit' prezenčnú formu štúdia a nahradit' ju dištančnou metódou výuky, čo ovplyvnilo vzdelávanie všetkých vyše 988 tisíc žiakov a študentov na Slovensku (UNESCO, 2020).

Slovensko kvôli reštrikčným opatreniam muselo pristúpit’ $\mathrm{k}$ využívaniu dištančnej formy vzdelávania v ovel'a väčšej miere ako doposial', od materských škôl až po vysokoškolských študentov. Za dištančnú formu vzdelávania považujeme „dial'kové vzdelávanie prostredníctvom korešpondencie, telekomunikačných médií a iných prostriedkov, bez priameho kontaktu medzi pedagogickým zamestnancom a samostatne študujúcim žiakom“ (Zákon č. 245/2008 Z.z., 2008, § 54 ods. 10). Niektoré školy už začali s využívaním elektronických informačných systémov, komunikácia prostredníctvom nich však bola určená najmä pre rodičov. Zabezpečit’ systém online vyučovania s rozvrhom, rozdelením žiakov do menších skupín a koordináciu učitelov, získanie platforiem na vyučovanie a preposielanie učiva a edukačných materiálov sa stalo výzvou pre všetky školy. Takisto uzatvorenie škôl a tried na Slovensku bolo doposial' skôr lokálneho charakteru a v časovo krátkom rozsahu, napríklad počas „chrípkových prázdnin“ alebo počas hromadného výskytu pedikulózy. V krajinách s častým výskytom epidémií, napr. v Hongkongu, v Austrálii a v Kanade (pandémia H1N1) je uzatvorenie škôl úspešným nefarmakologickým opatrením pri zmierňovaní šírenia ochorení, avšak nepoznáme presný rozsah jeho dopadov na deti a rodiny (Doyle, 2020). Podla našich vedomostí zatial' neexistuje žiadna medzinárodná štúdia, ktorá by mapovala účinky uzatvorenia všetkých školských zariadení na takéto dlhé obdobie, aké nastalo v roku 2020 v dôsledku nového koronavírusu. 
Viacerí odborníci (Bol, 2020; Cullinane, 2020; Doyle, 2020; Toseeb et al., 2020) poukazujú na riziko prehĺbenia nerovností vo vzdelávaní pri dlhodobejšom uzatvorení vzdelávacích inštitúcií. Štúdia z Holandska mapujúca žiakov od 4 do 18 rokov (Bol, 2020) ukázala prehlbovanie nerovností medzi det'mi zo znevýhodnených rodín a rodín, ktoré majú vyšší socio-ekonomický status. Takisto sa zvýrazňujú nerovnosti medzi samotnými školami v jednej krajine a ich možným materiálnym a technickým zabezpečením online výuky. V Anglicku analýza od Sutton Trust v edukačnom sektore poukázala na variabilitu v rámci dištančného vzdelávania medzi súkromnými a verejnými školami, rovnako aj medzi školami z bohatších a chudobnejších oblastí krajiny (Cullinane, 2020). Podobné závery uvádza aj Česká školní inspekce (2020) kde sa pri vzdelávaní na dial'ku na základných a stredných školách počas pandémie covid-19 ukázali zásadné rozdiely medzi regiónmi Českej republiky na úrovni riadenia školy, prístupe školy k vyučovaniu a tiež v podmienkach pre vzdelávanie na dial'ku.

V dôsledku odlišných podmienok sme tiež svedkami rozdielov v počte online vyučovacích hodín nielen v rámci škôl v jednej krajine, ale aj medzi krajinami vo svete. Rozdiely počas dištančného vzdelávania sa týkali celkového počtu hodín denne, ale aj počtu vyučovacích hodín na predmet týždenne. 0 rozdieloch $\mathrm{v}$ počte akademických hodín za deň a tiež v počte hodín venovaných určitému predmetu a ich dopadu na akademický výkon žiakov hovoria Burgess a Sievertsen (2020) a tiež Lavy (2015). Nakol'ko slovenské učebné osnovy neboli tvorené pre dištančné vzdelávanie, muselo sa od mnohých predmetov upustit', rovnako boli vylúčené aj niektoré témy z povinných predmetov $\mathrm{z}$ dôvodu nedostatku času $\mathrm{v}$ online priestore. $\mathrm{Z}$ aprílového prieskumu KPMG Business Institute (2020) s 330 slovenskými učitel'mi vyplýva, že polovica opýtaných učitel'ov odučila v priemere menej ako dve hodiny denne, tretina učitel'ov učí 3 až 4 hodiny denne. Žiaci po celom svete okrem online vyučovacích hodín mali k dispozícii aj rôzne vzdelávacie platformy, online knižnice a televízne programy, čo je d'alší z dôvodov, prečo sa môže počet vyučovacích hodín na diet'a líšit' (World Bank Group, 2020).

Na nedostatky v dištančnom vzdelávaní poukazuje aj štúdia Eduroma zo Slovenska, ktorá potvrdzuje, že žiaci z marginalizovaných rómskych komunít (MRK), aj napriek dostupnosti technických vymožeností, kvôli domácej situácii a nedostatku súkromia majú t’ažkosti s online vyučovaním a chýba im aj pedagogické vedenie učitela. Žiaci z MRK, ktorí nemajú technické zázemie a nie sú podporovaní prostredím, neboli pravidelne zapojení do dištančného 
vzdelávania. Prehĺbila sa segregácia chudobných a málo motivovaných žiakov z vylúčených komunít (Rafael \& Krejčíková, 2020). Dostupná literatúra mapujúca tažkosti dištančného vzdelávania počas korona krízy u detí bez špeciálnych potrieb poukazuje najmä na potreby materiálneho a technického zabezpečenia (Bol, 2020; Cullinane, 2020). Výsledky z prieskumu potrieb rodičov detí so ŠVVP vo veku od 4 do 18 rokov ukazujú na chýbajúce materiálne zabezpečenie, ale tiež aj na potreby pomoci a rady od špecialistu, potrebu pomoci a rád týkajúcich sa duševného stavu diet’ata, vyššiu podporu zo strany školy a tiež na potrebu d’alších podporných materiálov a návodov pre domáce učenie detí so špeciálnymi potrebami (Toseeb et al., 2020).

Viaceré práce tiež upozorňujú na psychologické dopady uzavretia vzdelávacích inštitúcií a opatrení zabezpečujúcich sociálny odstup na deti a mládež. Deti a mládež sa museli vyrovnat' so stratou osobného kontaktu s blízkymi a vrstovníkmi a tiež redukciou komunikácie s učitel’om alebo školským asistentom. Zaznamenaný bol tiež výskyt negatívnych emócií, frustrácie, nudy vznikajúcej z pocitu uväznenia $\mathrm{v}$ domácnosti, pocit nedostatku osobného priestoru a straty bežnej rutiny (Wang et al., 2020). Zvýšila sa tiež miera prežívania úzkosti a neistoty týkajúcej sa školy a priebehu vyučovacieho procesu, strachu z hodnotenia a obavy zo zvládnutia nového spôsobu vyučovania (Lades et al., 2020). Podl'a Wanga a kol. (2020) má takáto situácia negatívny dopad na mentálne zdravie detí a mládeže a zvyšuje ich psychosociálny stres. U mladých ludí sa zvýšil výskyt depresií a bol potvrdený nárast fyzického aj psychického násilia takmer vo všetkých krajinách (Campbell, 2020).

Uzatvorenie vzdelávacích inštitúcií malo priamy dopad nielen na edukáciu a mentálne zdravie detí, ale tiež na rodičov, ktorí museli v dôsledku situácie prijat' väčšiu mieru zodpovednosti za dohliadanie nad plnením školských povinností a zabezpečenie technických a materiálnych potrieb vzdelávania a to popri pracovnej činnosti a starostlivosti o domácnost'. Holandská štúdia poukázala na obavy rodičov súvisiace $\mathrm{s}$ kompetentnostou pomáhat' svojim det’om pri vzdelávaní počas korona krízy (Bol, 2020). Takmer $25 \%$ rodičov sa cítilo nekompetentných alebo málo kompetentných pri pomoci dietatu s edukáciou doma, najmä pre deti na stredných školách (Bol, 2020). Podobné výsledky reportuje aj štúdia z Írska, kde 39-40 \% rodičov pocitovalo vel'ké až vel'mi vel'ké obavy z domáceho vzdelávania (Doyle, 2020).

Štúdia z USA mapovala podiel dvoch partnerov v domácnosti na trávení času s det'mi do 17 rokov a pomáhaní pri ich vyučovacom procese. Napriek tomu, 
že sa zvýšil pobyt otca v domácnosti a trávenie jeho času s dietatóom, zodpovednost' za dodržiavanie učebných osnov alebo vytvorenie vzdelávacieho obsahu a jeho plánovanie vopred mala na starosti výhradne matka (50\% respondentov), z $12 \%$ mal zodpovednost' otec, $28 \%$ respondentov uviedlo rovnakú zodpovednost' partnerov. Výsledky tak poukazujú na vel'kú zátaž matky počas dištančného vzdelávania (Carlson, Petts, \& Pepin, 2020).

Okrem dopadu korona krízy na rodičov všeobecne, sa niektoré štúdie zamerali na vplyv korona krízy na rodičov detí so špeciálnymi potrebami. Štúdia v Anglicku poukázala na negatívny vplyv koronavírus pandémie na duševné zdravie rodičov detí so špeciálnymi potrebami a zdravotným znevýhodnením vo veku od 5 do 18 rokov. Rodičia pocitovali zvýšenú úzkost' aj stres. Taktiež sa u týchto rodičov objavila špecifická reakcia - obavy o budúcnost' dietatáa, aby ešte viac nezaostávali a neprišli o progres, ktorý doteraz dosiahli (Asbury et al., 2020).

Organizácia UNESCO Bangkok (2020) upozorňuje, že v zdravotných krízach, ako je aj korona kríza, sa zdravotne postihnutým osobám často poskytuje menšia pomoc a nedostatočne vyškolený personál. Deti so špeciálnymi potrebami taktiež negatívne ovplyvňuje postavenie mimo triedy, strata prístupu k spolužiakom a k hrám s nimi, čo je pre ich rozvoj rovnako dôležité ako samotné vzdelávanie. Vzdelávanie je u nich náročnejšie najmä kvôli času potrebnému na učenie a špeciálnym zdrojom a pomôckam. Zabezpečenie takýchto podmienok počas uzatvorenia škôl môže byt' pre ich rodiny z finančných, alebo iných dôvodov nerealizovatel'né (UNESCO Bangkok, 2020).

\section{Metodológia výskumu}

\subsection{Výskumné ciele}

Prerušenie vyučovania na školách a presun vzdelávania do domáceho prostredia $\mathrm{v}$ dôsledku pandémie koronavírusu predstavuje zvýšenú zátaž pre rodičov detí rôzneho veku. Špecifickou skupinou v tejto súvislosti sú rodičia detí so špeciálnymi výchovno-vzdelávacími potrebami (ŠVVP), pre ktorých môže táto situácia predstavovat' odlišné spektrum výziev. Ciel'om tohto výskumu je preto zmapovat' priebeh dištančného vzdelávania na Slovensku počas pandémie koronavírusu z perspektívy rodičov, pričom primárne sa zameriava na preskúmanie rozdielov medzi rodičmi detí so ŠVVP a rodičmi, ktorých deti nemajú identifikované špeciálne výchovno-vzdelávacie potreby v troch premenných: A) Čas venovaný domácej povinnej učebnej činnosti; 
B) Prežívanie rodiča vo vztahu k zabezpečovaniu domáceho vzdelávania; C) Plánovanie učebnej činnosti. Sekundárne si výskum kladie za ciel' popísat' prežívanie rodičov, ich obavy a potreby pri zabezpečovaní vzdelávania v domácom prostredí a rodičmi vnímanú participáciu školy.

\subsection{Metóda}

Pre účely výskumu bol vytvorený online dotazník, pozostávajúci zo 69 položiek v niekol'kých častiach. $\mathrm{V}$ úvode boli respondenti informovaní o účele výskumu, spôsobe zaobchádzania s dátami a následne boli požiadaní o vyjadrenie svojho súhlasu s účast'ou vo výskume. Ďalšia sekcia dotazníka bola venovaná základným sociodemografickým údajom (vek, pohlavie, vzdelanie, kraj a pod.), otázkam o počte a veku detí, prítomnosti špeciálnych výchovno-vzdelávacích potrieb detí, či otázkam o vlastnej skúsenosti s ochorením covid-19. Nasledujúce časti dotazníka sa zameriavali na zistovanie aktuálneho prežívania respondentov, sledovanie mediálnych správ a vnímanie opatrení v súvislosti s pandémiou koronavírusu. $\mathrm{V}$ predkladanom texte sa venujeme poslednej časti online dotazníka, ktorú tvorilo 14 položiek, z toho 9 uzavretých a 5 otvorených položiek, týkajúcich sa dištančného vzdelávania detí. V prípade uzavretých položiek respondenti označili svoju odpoved' na hodnotiacej škále, prípadne išlo o položky typu „ratio data“ (Mangal \& Mangal, 2013), kde respondenti zadávali číselný údaj, konkrétne počet hodín. Znenie jednotlivých položiek a spôsob odpovedania naň je bližšie opísaný v prílohe 1 . V závere dotazníka boli okrem pod’akovania uvedené telefonické a e-mailové kontakty, kde mohli respondenti v prípade potreby vyhladat' odbornú psychologickú pomoc a podporu.

\subsection{Zber dát}

Zber dát prebiehal v období od 14. 4. 2020 do 17. 5. 2020, teda v čase, kedy na Slovensku platili mimoriadne opatrenia $v$ dôsledku šírenia koronavírusu prerušujúce vyučovanie na školách a školských zariadeniach. Dotazník bol šírený v online priestore prostredníctvom webových a facebookových stránok Výskumného ústavu detskej psychológie a patopsychológie, online newslettera tejto inštitúcie, d'alej prostredníctvom facebookových skupín združujúcich rodičov, ktorí sa zaujímajú o problematiku školstva a dištančného vzdelávania a tiež bol zaslaný e-mailom združeniam rodičov detí s rôznymi špeciálnymi potrebami. Online dotazník bol šírený v dvoch jazykových verziách, v slovenskej a mad'arskej. 


\subsection{Výskumná vzorka}

Výskumnú vzorku tvorilo 462 respondentov, z toho 428 žien a 32 mužov, 2 respondenti neuviedli pohlavie. Vek respondentov sa pohyboval od 25 do 62 rokov, pričom priemerný vek bol 40,73 rokov $\left(\mathrm{SD}^{2}=5,80\right)$. Respondenti sú rodičmi jedného až siedmich detí vo veku od niekol'ko mesiacov až po 35 rokov $\left(\mathrm{M}^{3}=11,13 ; \mathrm{Md}^{4}=10, \mathrm{SD}=6,07\right)$. Rodičia detí so špeciálnymi výchovno-vzdelávacími potrebami tvorili $20,6 \%$ výskumnej vzorky $\left(\mathrm{N}^{5}=95\right)$, pričom súčastou tejto skupiny boli rodičia detí so zdravotným znevýhodnením (vývinové poruchy učenia, poruchy aktivity a pozornosti, narušená komunikačná schopnost', poruchy autistického spektra, telesné postihnutie, mentálne postihnutie, viacnásobné postihnutie), ako aj rodičia detí s intelektovým nadaním. Slovenskú verziu dotazníka vyplnilo 80,7 \% (N = 373) respondentov, zvyšných 19,3 \% (N = 89) respondentov vyplnilo dotazník v mad'arskej jazykovej verzii. Z pohl'adu bydliska respondentov je vo vzorke zastúpených všetkých 8 krajov Slovenska (vid' Obr. 1), pričom najviac, 20,1 \% respondentov, pochádza z Bratislavského kraja. Až 52,4\% respondentov udáva vysokoškolské vzdelanie (vid'. obr. 1). Žiadny z respondentov neuviedol osobnú skúsenost' s ochorením covid-19, no 14 respondentov $(3,0 \%)$ malo blízkeho či známeho, ktorý bol nakazený koronavírusom. Použitý bol príležitostný výber výskumnej vzorky.
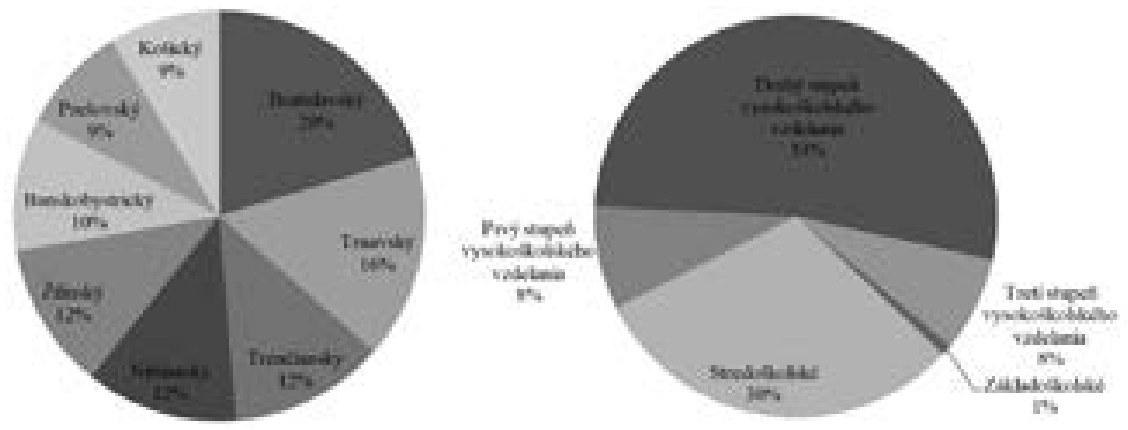

Obrázok 1. Rozloženie výskumnej vzorky podl’a bydliska a najvyššieho dosiahnutého vzdelania. 


\subsection{Spracovanie výskumných dát}

Dáta boli spracované pomocou programu SPSS ver. 22 for Windows. Boli použité metódy deskriptívnej štatistiky (frekvencia, priemer, štandardná odchýlka a štandardná chyba priemeru, minimum a maximum) a metódy inferenčnej štatistiky (testy normality distribúcie dát, korelačné koeficienty a komparačné analýzy). Pri testovaní inferenčnými testami bola overená normalita distribúcie dát pomocou Kolmogorovho-Smirnovovho testu (pri všetkých položkách hladina významnosti p bola > 0,05; Tomšik, 2017), na základe ktorého boli použité d’alšie parametrické testy pre analýzu dát: Studentov t-test a Pearsonov koeficient korelácie. Grafy boli vytvorené pomocou programu MS Excel. Otvorené otázky boli konceptualizované a následne kategorizované. Otázky boli analyzované dvoma výskumníkmi. Následne boli jednotlivé kategórie komparované za cielom zvýšenia spolahlivosti.

\section{Výsledky}

Ako prvé boli štatistickej analýze podrobené odpovede na otázku mapujúcu počet hodín, ktoré deti podla výpovedí rodičov denne venujú povinnej učebnej činnosti. Jej výsledky uvádzame $v$ tabul'ke 1 . Z celkového počtu žiakov so ŠVVP bolo 9,9 \% žiakov, ktorí ukončili povinnú školskú dochádzku, resp. nenavštevujú školu; 12,3 \% bolo žiakov, ktorí navštevovali materskú alebo špeciálnu materskú školu; a 5,21 \% bolo študentov vysokých škôl. U týchto žiakov a študentov neboli analyzované počty hodín, ktoré venovali povinnej učebnej činnosti. Špeciálne školy (aj pre nadaných) a liečebno-výchovné sanatórium navštevovalo spolu 6,8 \% zo žiakov. Ostatní žiaci $(63,1 \%)$ navštevovali bežné základné a stredné školy. Počet hodín je pomerne rovnomerne distribuovaný vo všetkých výskumných podskupinách. Žiaci navštevujúci 1. stupeň základných škôl venovali podla výpovedí rodičov približne $\mathrm{M}=2,9$ hodín denne povinnej učebnej činnosti. Žiaci so ŠVVP venovali povinnej učebnej činnosti o približne 0,25 hodín denne menej, v porovnaní s det'mi bez špeciálnych potrieb. Podobné zistenia evidujeme aj pri žiakoch navštevujúcich stredné Školy, kde žiaci so ŠVVP venovali povinnej učebnej činnosti podla výpovedí rodičov menej času denne ako žiaci bez ŠVVP. Opačné zistenia sú pri žiakoch navštevujúcich 2 . stupeň základných škôl. V tomto prípade, žiaci so ŠVVP venovali denne povinnej učebnej činnosti viac času, v porovnaní so žiakmi bez ŠVVP. Rozdiel evidujeme aj medzi jednotlivými stupňami vzdelávania, kde žiaci navštevujúci 2 . stupeň základných škôl a stredné školy, venovali povinnej učebnej činnosti viac času denne, v porovnaní so žiakmi navštevujúcimi 1. stupeň základných škôl. 
Tabul'ka 1

Čas venovaný domácej povinnej učebnej činnosti

\begin{tabular}{|c|c|c|c|c|c|c|c|c|}
\hline Skupiny & & $\mathrm{Nr}$ & $\mathrm{Nd}$ & $\mathrm{M}$ & SD & SEM & MIN & MAX \\
\hline \multirow[t]{3}{*}{$\begin{array}{l}\text { Rodičia detí } \\
\text { so ŠVVP }\end{array}$} & $\begin{array}{l}\text { Žiaci } \\
\text { 1. st. ZŠ }\end{array}$ & 95 & 67 & 2,70 & 1,51 & 0,19 & 0 & 8 \\
\hline & $\begin{array}{l}\text { Žiaci } \\
\text { 2. st. ZŠ }\end{array}$ & & 65 & 3,92 & 1,73 & 0,21 & 0 & 10 \\
\hline & Žiaci SŠ & & 20 & 3,11 & 1,49 & 0,34 & 1 & 6 \\
\hline \multirow[t]{3}{*}{$\begin{array}{l}\text { Rodičia detí } \\
\text { bez ŠVVP }\end{array}$} & $\begin{array}{l}\text { Žiaci } \\
\text { 1. st. ZŠ }\end{array}$ & 365 & 218 & 2,95 & 1,35 & 0,09 & 0 & 9 \\
\hline & $\begin{array}{l}\text { Žiaci } \\
\text { 2. st. ZŠ }\end{array}$ & & 172 & 3,59 & 1,72 & 0,13 & 0 & 10 \\
\hline & Žiaci SŠ & & 112 & 3,92 & 1,90 & 0,18 & 0 & 10 \\
\hline \multirow[t]{3}{*}{ Spolu } & $\begin{array}{l}\text { Žiaci } \\
\text { 1. st. ZŠ }\end{array}$ & 460 & 285 & 2,89 & 1,39 & 0,08 & 0 & 9 \\
\hline & $\begin{array}{l}\text { Žiaci } \\
\text { 2. st. ZŠ }\end{array}$ & & 238 & 3,67 & 1,73 & 0,11 & 0 & 10 \\
\hline & Žiaci SŠ & & 132 & 3,53 & 1,87 & 0,20 & 0 & 10 \\
\hline
\end{tabular}

Pozn.: Nr - počet rodičov; Nd - počet žiakov; M - priemer; SD - štandardná odchýlka; SEM - štandardná chyba priemeru; ŠVVP - špeciálne výchovno-vzdelávacie potreby.

V d’alšej časti uvádzame výsledky opisnej a inferenčnej štatistiky troch položiek zist'ujúcich pocity rodičov pri edukácii svojich detí (osobné kompetencie pri vzdelávaní; obavy zo vzdelávania v domácom prostredí; tlak na rodičov pri vzdelávaní $v$ domácom prostredí). Vo všetkých troch otázkach rodičia odpovedali pomocou miery súhlasu/nesúhlasu na škále od 1 (rozhodne nesúhlasím) do 5 (rozhodne súhlasím). Približne 19,9 \% rodičov súhlasilo, že sa necítia byt' kompetentní pri edukácii ich detí, kým 54,5 \% rodičov s týmto výrokom nesúhlasili. Približne 30,9 \% rodičov súhlasilo, že majú obavy, že ich diet'a/deti nezíska/jú dostatočné vedomosti a rozvoj, kým 48,9 \% rodičov s týmto výrokom nesúhlasilo. Vo všetkých troch položkách sa priemer odpovedí pohybuje okolo aritmetického priemeru škály (3), resp. je zanedbatel'ne nižší ako uvedená hodnota. Medzi výskumnými skupinami (rodičia detí bez ŠVVP a rodičia detí so ŠVVP) neexistuje štatisticky významný rozdiel ani v jednej zo skúmaných premenných $(<0,05)$. Napriek tomu, medzi výskumnými premennými bol zistený štatisticky významný vztah: rodičia, ktorí sa cítia byt' menej kompetentní pri vzdelávaní svojich detí doma, majú 
tendenciu intenzívnejšie prežívat' obavy, že ich dieta doma nezíska dostatočné vedomosti $(\mathrm{r}=0,448 ; \mathrm{p}<0,001)$ a intenzívnejšie pocitujú psychický tlak pri zastupovaní učitelov $\mathrm{v}$ domácom vzdelávaní počas koronavírus pandémie $(\mathrm{r}=0,336 ; \mathrm{p}<0,001)$.

\section{Tabul'ka 2}

Prežívanie rodiča vo vzt'ahu $k$ zabezpečovaniu vzdelávania $v$ domácom prostredí počas koronavírus pandémie

\begin{tabular}{|c|c|c|c|c|c|c|c|}
\hline Výrok & Skupiny & $\mathrm{N}$ & M & SEM & SD & $\mathrm{t}$ & $\mathrm{P}$ \\
\hline \multirow[t]{3}{*}{$\begin{array}{l}\text { A) Necítim sa byt' dostatočne } \\
\text { kompetentný/á pri vzdelávaní } \\
\text { môjho/mojich diet’at'a/detí, } \\
\text { ktoré musím robit' počas } \\
\text { koronavírus pandémie }\end{array}$} & $\begin{array}{l}\text { Rodičia detí } \\
\text { bez ŠVVP }\end{array}$ & 360 & 2,37 & 0,06 & 1,27 & 0,783 & 0,434 \\
\hline & $\begin{array}{c}\text { Rodičia detí } \\
\text { so ŠVVP }\end{array}$ & 93 & 2,48 & 0,13 & 1,32 & & \\
\hline & Spolu & 453 & 2,43 & 0,06 & 1,28 & & \\
\hline \multirow[t]{3}{*}{$\begin{array}{l}\text { B) Mám obavy, že moje diet’a/ti } \\
\text { doma nezíska/jú dostatočné } \\
\text { vedomosti a rozvoj počas } \\
\text { koronavírus pandémie }\end{array}$} & $\begin{array}{c}\text { Rodičia detí } \\
\text { bez ŠVVP }\end{array}$ & 359 & 2,70 & 0,07 & 1,41 & 1,207 & 0,230 \\
\hline & $\begin{array}{c}\text { Rodičia detí } \\
\text { so ŠVVP }\end{array}$ & 94 & 2,50 & 0,14 & 1,42 & & \\
\hline & Spolu & 453 & 2,60 & 0,06 & 1,41 & & \\
\hline \multirow[t]{3}{*}{$\begin{array}{l}\text { C) Vymedzte vel'kost' tlaku, ktorý } \\
\text { pocit’ujete pri zastupovaní } \\
\text { učitelov v domácom vzdelávaní } \\
\text { počas koronavírus pandémie }\end{array}$} & $\begin{array}{c}\text { Rodičia detí } \\
\text { bez ŠVVP }\end{array}$ & 355 & 2,68 & 1,30 & 0,06 & 1,877 & 0,061 \\
\hline & $\begin{array}{c}\text { Rodičia detí } \\
\text { so ŠVVP }\end{array}$ & 91 & 2,97 & 1,38 & 0,14 & & \\
\hline & Spolu & 446 & 2,82 & 0,06 & 1,32 & & \\
\hline
\end{tabular}

Pozn.: N - počet; M - priemer; SD - štandardná odchýlka; SEM - štandardná chyba priemeru; t -Studentov t-test; $\mathrm{p}$ - hladina štatistickej významnosti; ŠVVP - špeciálne výchovno-vzdelávacie potreby.

Výsledky analýz odpovedí na položky zamerané na zistenie spôsobu plánovania učebnej činnosti žiakov rodičmi sú uvedené v tabul'ke 3. Približne $51,1 \%(N=236)$ čiastočne plánovalo vopred učebnú činnost' žiakov, kým iba $16,5 \%(N=76)$ plánovalo podrobne vopred učebnú činnost' žiakov. Rodičia 
s det'mi so ŠVVP dávali väčší dôraz na plánovanie učebnej činnosti svojich detí (čiastočne $58,9 \%, \mathrm{~N}=56$; podrobne $22,1 \%, \mathrm{~N}=21$ ), v porovnaní s rodičmi detí bez ŠVVP (čiastočne 49,4 \%, N = 178; podrobne 15,3 \%, N = 55). Zapojenie učitel'ov do domácej učebnej činnosti rodičia v oboch skupinách vnímajú vel'mi podobne. Približne 12,5 \% rodičov odpovedalo, že sa učitelia na tejto činnosti nepodielali. Viac ako 87,5 \% rodičov uviedlo, že im učitelia čiastočne alebo plne pomáhalo pri plánovaní učebnej činnosti ich detí.

Porovnatel'né zastúpenie odpovedí v oboch výskumných podskupinách bolo zistené aj pri poslednej položke mapujúcej del'bu učebnej činnosti medzi rodičmi. Iba $14,1 \%$ rodičov sa na učebnej činnosti detí podiel'alo rovnomerne, kým iba 13,8 \% uviedlo, že im partner/partnerka signifikantne pomáha pri tejto činnosti. Vyše 72,1 \% rodičov uviedlo, že túto činnosti vykonávajú sami, resp. že im partner pomáha len vel'mi málo (33,7 \% v celom súbore). Je nevyhnutné poznamenat', že z celkového počtu respondentov bolo 417 žien a 29 mužov, z ktorých iba 7 uviedli, že im partnerky málo alebo vôbec nepomáhali pri učebnej činnosti detí.

Tabul'ka 3

Plánovanie učebnej činnosti

\begin{tabular}{llcccccc}
\hline \multirow{2}{*}{ Otázky } & Odpovede & \multicolumn{2}{c}{$\begin{array}{c}\text { Rodičia detí } \\
\text { So ŠVVP }\end{array}$} & \multicolumn{2}{c}{$\begin{array}{c}\text { Rodičia detí } \\
\text { bez ŠVVP }\end{array}$} & \multicolumn{2}{c}{ Spolu } \\
\cline { 2 - 8 } & & $\mathrm{N}$ & $\%$ & $\mathrm{~N}$ & $\%$ & $\mathrm{~N}$ & $\%$ \\
\hline $\begin{array}{l}\text { D) Plánujete vopred učebnú } \\
\text { činnost' diet'at'a? }\end{array}$ & Nie & 18 & 18,9 & 127 & 35,3 & 145 & 31,7 \\
\hline & Čiastočne & 56 & 58,9 & 178 & 49,4 & 236 & 51,6 \\
\hline & Áno, vel'mi & 21 & 22,1 & 55 & 15,3 & 76 & 16,6 \\
& podrobne & & & & & & \\
\hline & Spolu & 95 & 100,0 & 360 & 100,0 & 457 & 100,0 \\
\hline $\begin{array}{l}\text { E) Podielajú sa učitelia Vášho/ } \\
\text { Vašich diet’at’a/detí na } \\
\text { plánovaní učebnej činnosti? }\end{array}$ & Nie & 12 & 12,6 & 45 & 12,5 & 57 & 12,5 \\
\hline & Čiastočne & 38 & 40,0 & 130 & 36,1 & 169 & 37,0 \\
\hline & Áno & 45 & 47,4 & 185 & 51,4 & 231 & 50,5 \\
\hline & Spolu & 95 & 100,0 & 360 & 100,0 & 457 & 100,0 \\
\hline & Nie & 34 & 36,6 & 138 & 39,1 & 172 & 38,4 \\
\hline $\begin{array}{l}\text { F) Podiel'a sa Váš partner } \\
\text { na povinnej učebnej činnosti? }\end{array}$ & Len málo & 35 & 37,6 & 116 & 32,9 & 151 & 33,7 \\
\hline & & & & & & & \\
\hline
\end{tabular}




\begin{tabular}{llccccccc}
\hline Otázky & Odpovede & \multicolumn{2}{c}{$\begin{array}{c}\text { Rodičia detí } \\
\text { so ŠVVP }\end{array}$} & \multicolumn{2}{c}{$\begin{array}{c}\text { Rodičia detí } \\
\text { bez ŠVVP }\end{array}$} & \multicolumn{2}{c}{ Spolu } \\
\cline { 2 - 8 } & & $\mathrm{N}$ & $\%$ & $\mathrm{~N}$ & $\%$ & $\mathrm{~N}$ & $\%$ \\
\hline & $\begin{array}{l}\text { Vel'mi mi } \\
\text { pomáha }\end{array}$ & 13 & 14,0 & 48 & 13,6 & 62 & 13,8 \\
\hline $\begin{array}{l}\text { Delíme túto } \\
\text { činnost' } \\
\text { rovnomerne }\end{array}$ & 11 & 11,8 & 51 & 14,4 & 63 & 14,1 \\
\hline Spolu & 93 & 100,0 & 353 & 100,0 & 448 & 100,0 \\
\hline
\end{tabular}

Pozn.: N - počet; ŠVVP - špeciálne výchovno-vzdelávacie potreby.

V nasledujúcej časti uvádzame sumarizáciu výsledkov nasledovných otvorených otázok: A) Aké materiály, prostriedky alebo pomôcky Vám chýbajú pri učebnej činnosti Vašich detí počas koronavírus pandémie?; B) Z čoho máte ešte obavy? (vo vzt'ahu k učivu, škole, známkam, atd'); C) Z čoho má/jú Vaše dieta/ti obavy počas koronavírus pandémie? (vo vzt'ahu k učivu, škole, známkam, atd'); D) Čo by Vám pomohlo pri vzdelávaní detí doma počas koronavírus pandémie?; E) Uved'te, $v$ čom vidíte nedostatky zo strany školy pri vzdelávaní Vašich detí počas pandémie.

Na prvú otázku bolo získaných 285 odpovedí, z čoho 77 bolo od rodičov detí so ŠVVP. Výsledky sú graficky znázornené na obrázku 2, v ktorom pre komparáciu uvádzame percentuálnu distribúciu odpovedí v jednotlivých výskumných podskupinách. Spolu 35,8 \% rodičov uviedlo, že pri domácom vzdelávaní im nechýbajú žiadne pomôcky, prostriedky alebo materiály $(24,7$ \% rodičov s det'mi so ŠVVP; 39,9 \% rodičov detí bez špeciálnych potrieb). Ďalšou najčastejšou odpoved'ou boli Učebnice, skriptá, zošity, pracovné listy $(13,7 \%)$ a Tlačiareň/Toner/Notebook/Internet/Iná technika (15,1\%), kde práve v tejto kategórii zaznamenávame najväčší rozdiel medzi výskumnými podskupinami.

Rodičia s det'mi so ŠVVP uvádzali častejšie absenciu technických a elektronických pomôcok $(23,4 \%)$ v porovnaní s rodičmi detí bez špeciálnych potrieb (12,0 \%). Ďalšie menšie rozdiely zaznamenávame aj v kategóriách Video a audio materiály/Online vyučovanie a Pedagogická a didaktická pomoc/ Online podpora, ktoré rodičia detí so ŠVVP $(13,0 \% / 10,4 \%)$ uvádzali častejšie, v porovnaní s rodičmi detí bez špeciálnych potrieb $(6,7$ \%/6,3 \%). 


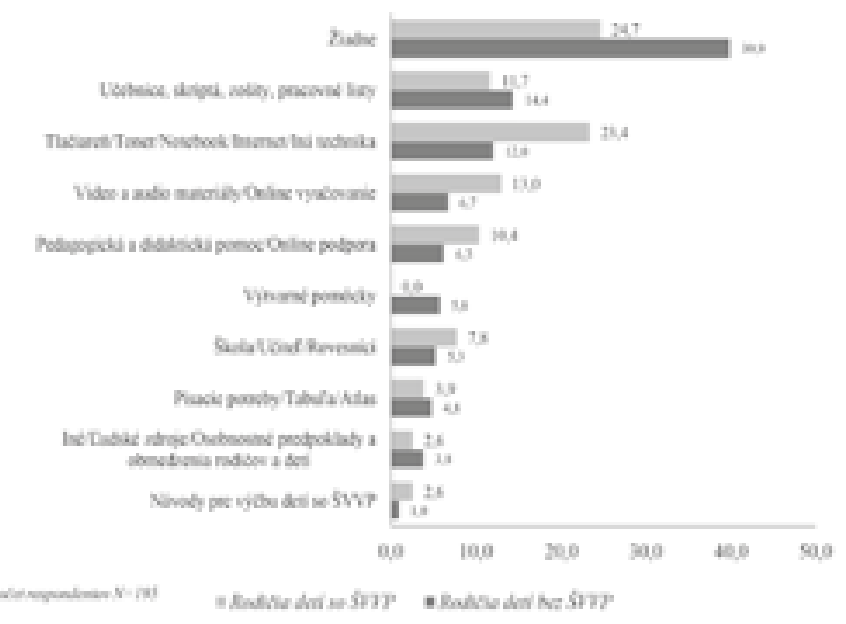

Obrázok 2. Materiály, prostriedky, alebo pomôcky, ktoré rodičom absentovali pri učebnej činnosti detí počas koronavírus pandémie.

Ďalšie dve otvorené otázky boli zamerané na mapovanie obáv rodičov a detí vo vztáahu ku škole/učivu a celkovo vzniknutej situácii: $B$ ) $Z$ čoho máte ešte obavy? (vo vzt'ahu k učivu, škole, známkam, atd'; 384 odpovedí); C) Z čoho má/ jú Vaše diet'a/ti obavy počas koronavírus pandémie? (vo vzt'ahu $k$ učivu, škole, známkam, atd'; 333 odpovedí).

V otázke B) 15,9 \% rodičov uviedlo, že pri domácom vzdelávaní nemali žiadne obavy vo vztaha ku školským povinnostiam ich detí. Najčastejšie uvádzanou odpoved'ou bolo Zvládnutie školských povinností/Preberanie povinného učiva či obavy, že s det'mi neprebrali dostatok učiva $(21,4 \%)$. Ďalšie frekventované kategórie pre obe skupiny boli Absencia učitela/ky a osobných zručností spojených s vyučovaním detí (11,2 \%), Komunikácia a spolupráca s učitel'mi/kami a školou / Objektívnost' hodnotenia (10,2 \%) a Dopady aktuáIneho spôsobu vyučovania na zdravie detí, a na ich osobnostné charakteristiky (napríklad: motivácia, lenivost', strata disciplíny....; 9,4 \%).

V otázke B) boli odpovede porovnatel'ne distribuované medzi výskumnými podskupinami, až na niekol'ko výnimiek. Prirodzene, rodičia detí so ŠVVP pocit’ovali absenciu špecialistov pri vzdelávaní ich detí (9,4\%; bez vol'by v skupine rodičov detí bez špeciálnych potrieb), a vyjadrili, že mali väčší problém 
s financiami, organizáciou domácnosti a časom pre vyučovanie detí $(9,4 \%)$, v porovnaní s rodičmi detí bez špeciálnych potrieb (3,6 \%). Kým na druhej strane, rodičia detí bez špeciálnych potrieb sa častejšie obávali vzdelávacej stránky a uvádzali častejšie kategórie: Návrat do školy (aklimatizácia), Nedostatok získaných praktických zručností, Nedostatok získaných vedomostí (vid' obr. 3).

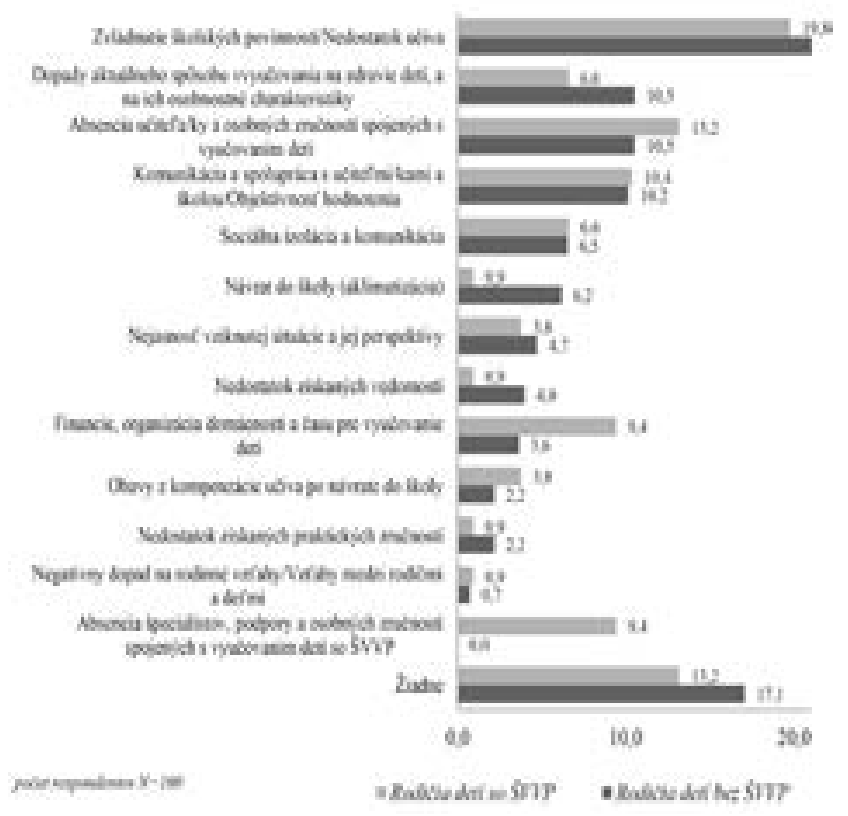

Obrázok 3. Obavy rodičov vo vztahu k učivu a iným školským povinnostiam.

V otázke C) Z čoho má/jú Vaše diet'a/ti obavy počas koronavírus pandémie? (vo vzt'ahu $k$ učivu, škole, známkam, atd.; 333 odpovedí), rodičia najčastejšie uvádzali, že ich deti nemali žiadne starosti vo vzt'ahu ku škole a učivu, konkrétne 33,0 \%. Ďalšie často volené kategórie boli spojené s bežným životom a bežnými školskými povinnostami: Absencia sociálnych kontaktov/ Rovesníkov/íčiek/Učitelov/liek (18,0 \%), Obavy z nezvládnutia školských povinností $(10,6 \%)$ a Obavy z bežných školských povinností $(11,0 \%)$. Drobné 
rozdiely v distribúcii odpovedí zaznamenávame iba v kategóriách Obavy z nezvládnutia školských povinností, Problémy s aktuálnym spôsobom výučby, Problémy spojené s vyučujúcimi a školou (komunikácia, dôslednost', zaobstaranie materiálov...), kde rodičia detí bez ŠVVP uvádzali tieto kategórie častejšie, kým kategóriu Absencia sociálnych kontaktov/Rovesníkov/íčiek/Učitelov/liek uvádzali častejšie rodičia detí so ŠVVP.

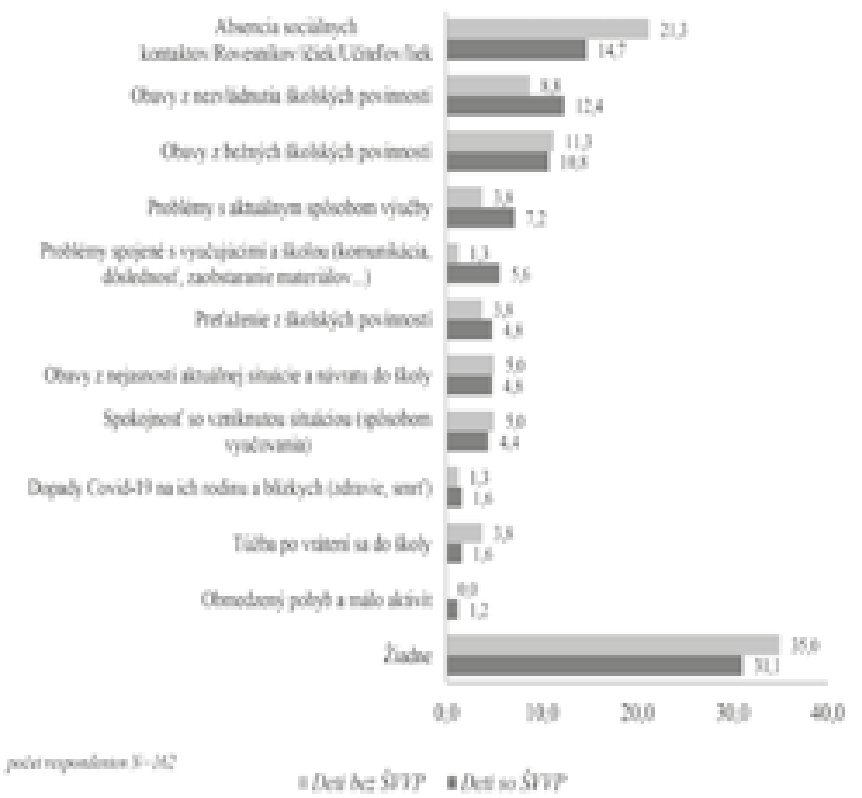

Obrázok 4. Obavy detí počas koronavírus pandémie.

V otázke D) Čo by Vám pomohlo pri vzdelávaní detí doma počas koronavírus pandémie? rodičia najčastejšie uvádzali nedostatok online materiálov, či online vyučovania $(27,6$ \%). Ďalšie frekventované kategórie boli faktory zaradené ako iné (školská jedáleň, otvorenie školy a pod.), či odpoved' neviem (9,2 \%); a kategória kde sa rodičia vyjadrili, že mali všetky potrebné prostriedky zaobstarané (8,2 \%). Výraznejší rozdiel však evidujeme v kategórii Podpora odborníka (logopéd, špeciálny pedagóg, psychológ), ktorú prirodzene častejšie uvádzali rodičia detí so ŠVVP a Lepšia komunikácia učitela, školy, 
konzultácie, ktorú tiež častejšie uvádzali rodičia detí so ŠVVP. Rodičia detí bez špeciálnych potrieb v tejto otázke častejšie volili iba kategórie späté so samotným vyučovaním a organizáciou vyučovania: Rozvrh hodín, harmonogram a Metodická podpora pre rodiča, vedomosti. Napriek tomu, medzi výskumnými skupinami v týchto kategóriách nezaznamenávame markantný rozdiel (vid' obr. 5).

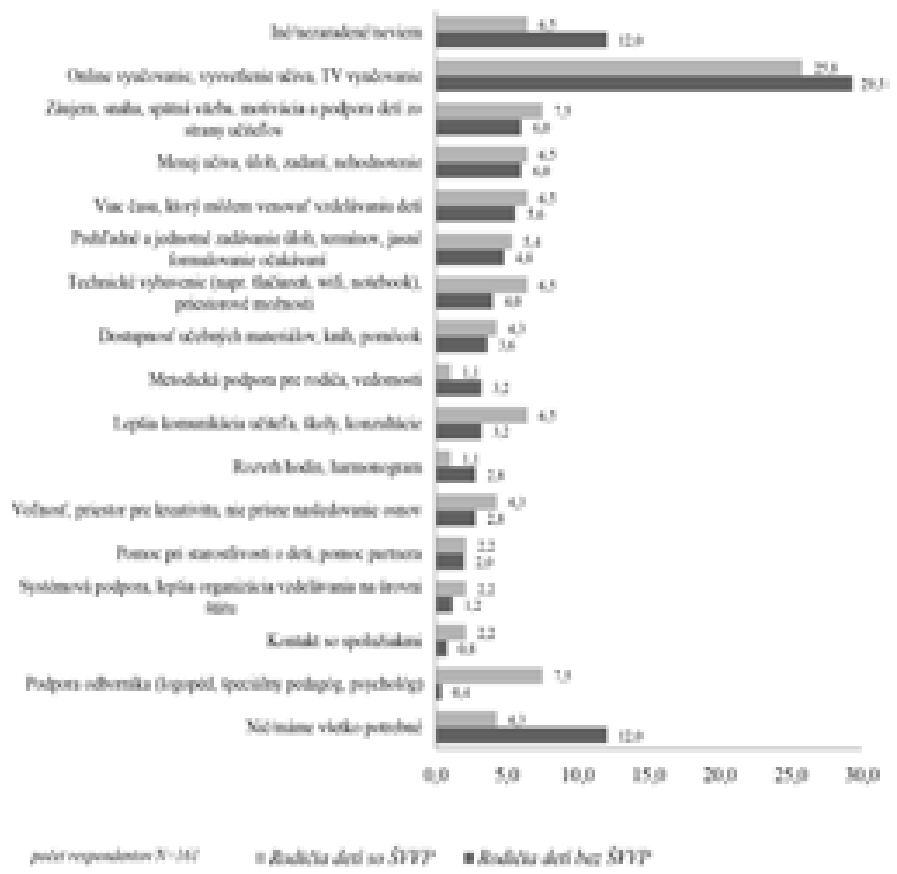

Obrázok 5. Pomoc pri vzdelávaní počas koronavírus pandémie (výpovede rodičov).

V poslednej otázke E) Uved'te, $v$ čom vidíte nedostatky zo strany školy pri vzdelávaní Vašich detí počas pandémie, sme zaznamenali 531 odpovedí. Približne 23,2 \% rodičov uviedlo, že nevidia nedostatky v kooperácii so školou pri vzdelávaní ich detí počas pandémie. Rozdiel v tejto kategórii bol väčší medzi výskumnými skupinami, kde rodičia detí bez ŠVVP vnímali spoluprácu so 
školou ako viac problematickejšiu $(28,5 \%)$ v porovnaní s rodičmi detí so ŠVVP (17,9 \%) z pohladu tejto kategórie. Napriek tomu, d'alšie najčastejšie uvádzané kategórie boli Zlá organizácia, nesystematickost', nejednotnost' $v$ prístupe učitelov $(12,9 \%)$ a Chýba/nedostatok online vyučovania, kontakt s učitelom $(19,7 \%$ ), avšak rodičia detí so ŠVVP tieto kategórie uvádzali výrazne častejšie. Rodičia detí bez ŠVVP mali skôr problém so samotným vysvetlovaním učebnej látky.

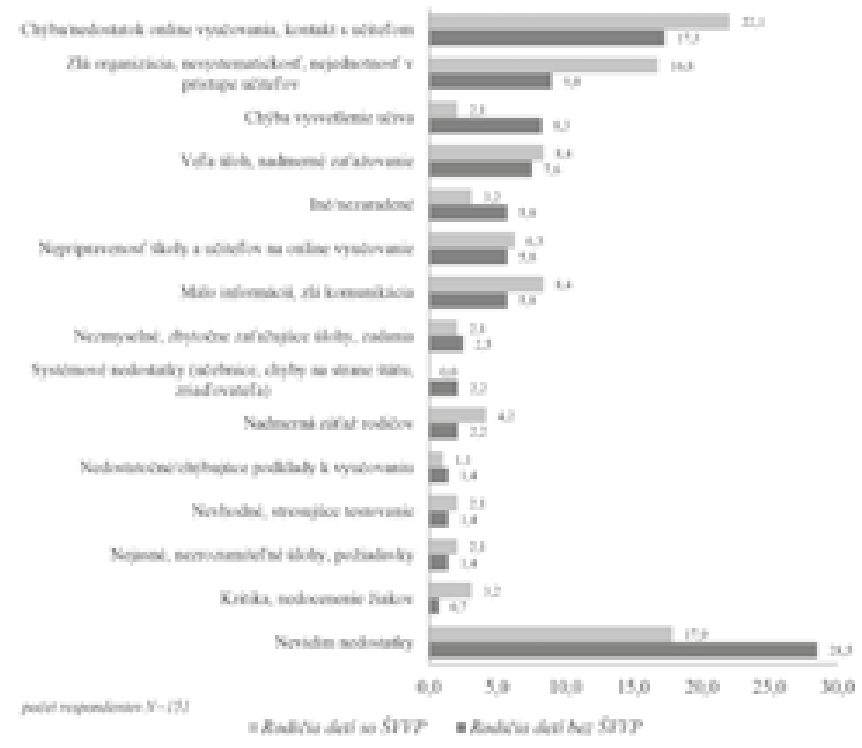

Obrázok 6. Nedostatky zo strany školy pri vzdelávaní detí počas pandémie z pohladu rodičov.

\section{Diskusia}

V predkladanom výskume mapujeme priebeh vzdelávania v domácom prostredí na Slovensku z pohl'adu rodičov počas pandémie koronavírusu v období, kedy platili mimoriadne opatrenia a boli uzatvorené všetky vzdelávacie inštitúcie. Výskumu sa zúčastnilo 462 rodičov zo všetkých krajov Slovenska. 
Jednou z často diskutovaných otázok v súvislosti s dištančným vzdelávaním v tomto období bol počet hodín, ktoré počas dňa deti venujú učeniu. Rodičia v našej výskumnej vzorke udávali, že deti navštevujúce 1 . stupeň ZŠ sa denne učia v priemere 2,89 hodín, žiaci na 2 . stupni ZŠ 3,67 hodín a stredoškoláci 3,53 hodín. Podla výpovedí rodičov teda priemerný žiak venuje učebnej činnosti viac času ako odporúča usmernenie Ministerstva školstva, podla ktorého žiak 1-3. ročníka by mal mat' časovú zátaž pri dištančnom vzdelávaní v rozpätí 5-8 hodín týždenne, v 4-5. ročníku 8-10 hodín týždenne a na druhom stupni sa odporúčaná časová zátaž pohybuje v rozmedzí 10-15 hodín týždenne (MŠVVaŠ SR, 2020a). Pri porovnaní s inými krajinami sa ukazuje, že naši žiaci sa učeniu počas pandémie venovali približne tak dlho ako žiaci v USA (Carlson et al., 2020), no viac ako žiaci z Írska, kde sa 52 \% žiakov učilo v priemere 1-2 hodiny (Doyle, 2020). Dáta z prieskumu v Českej republike ukázali, že 72 \% žiakov základných škôl sa učilo 2-4 hodiny denne (Brom et al., 2020), čo je porovnatel'né s našimi dátami.

Pokial' ide o žiakov so ŠVVP, najväčší rozdiel v počte učeniu venovaných hodín sme zaznamenali u stredoškolákov, ktorí sa podl'a rodičov učili v priemere o 0,81 hodiny menej ako žiaci bez identifikovaných špeciálnych potrieb. Tento rozdiel môže byt' spôsobený možnými t'ažkostami týchto detí prispôsobit' sa zmeneným podmienkam vzdelávania, ktoré im z rôznych dôvodov nevyhovujú alebo nepodporujú ich v progrese ako uvádza aj Toseeb a kol. (2020), pričom pri náročnejšom vzdelávacom obsahu na stredných školách sa tieto t’ažkosti môžu prejavit' viac. Ako uvádza Lee (2020) u žiakov so ŠVVP a najmä žiakov s rôznym stupňom autistického spektra môže dochádzat' $\mathrm{k}$ frustračným reakciám aj $\mathrm{k}$ prchkému správaniu, čo môže komplikovat' edukačný proces doma. Ministerstvo školstva, vedy, výskumu a športu ŠR vydalo dňa 28.4.2020 metodické usmernenie týkajúce sa obsahu a organizácie vyučovania doma, kde uvádza, že počas dištančného vzdelávania by sa malo u detí s rozmanitými potrebami, so zdravotným znevýhodnením a mentálnym postihnutím venovat' najmä prehlbovaniu nadobudnutých vedomostí a schopností (MŠVVaŠ SR, 2020b).

Počet hodín, ktoré žiaci venovali učebnej činnosti počas dištančného vzdelávania, môže byt' ovplyvnený mnohými premennými, od materiálneho zabezpečenia, podmienok školy a jednotlivých domácností, cez potreby dietatáa aj časových možností samotného rodiča. $V$ našom výskume väčšina rodičov detí so ŠVVP (81 \%) uviedla, že vopred plánovala učebnú činnost' svojich 
detí. V prípade rodičov detí bez špeciálnych potrieb je to $65 \%$. Toto zistenie je v súlade s odporúčaniami mnohých organizácií, ktoré sa venujú detom so špeciálnymi potrebami, aby sa im vytvorila každodenná rutina, ktorá by vyhovovala ako dietat'u tak rodičom $v$ súlade $\mathrm{s}$ ich pracovnou náplňou a možnost'ami (Toseeb et al., 2020). Lee (2020) prisudzuje plánovaniu učebnej činnosti dôležitú úlohu pri znižovaní neistoty a úzkosti u detí so ŠVVP, ktorá bola spôsobená narušením ich školskej rutiny. Pokial' ide o zdielanie rodičovskej účasti na vzdelávaní detí medzi partnermi, viac ako tretina respondentov uviedla, že partner sa na tejto činnosti nepodiela vôbec a d'alšia tretina respondentov uviedla iba malý podiel účasti partnera. Iba $14 \%$ rodičov uviedlo rovnomerné delenie tejto činnosti medzi partnermi. Vzhladom na vysoké zastúpenie žien v našej výskumnej vzorke možno predpokladat', že vo väčšine slovenských rodín sa učebnej činnosti detí venovali najmä matky. Podobné výsledky možno nájst' aj v americkej štúdii Carlsona a kol. (2020), kde u 62 \% respondentov mal vzdelávanie doma na starosti jeden z partnerov, zatial' čo rovnakú mieru aktívnej účasti partnerov na domácom vzdelávaní uviedlo $28 \%$ opýtaných.

Väčšina rodičov z našej výskumnej vzorky sa pri svojej účasti na vzdelávaní detí cíti dostatočne kompetentne. Menej kompetentní alebo nekompetentní sa cíti byt' takmer $20 \%$ opýtaných rodičov. Podobné dáta priniesla aj štúdia z Holandska, kde sa takmer $25 \%$ rodičov cítilo nekompetentných alebo málo kompetentných pri pomoci diet’atu s edukáciou doma, najmä u žiakov stredných škôl (Bol, 2020). Taktiež v prieskume z Českej republiky, niektorým rodičom žiakov základných škôl komplikoval učenie doma najmä nedostatok odborných znalostí, či už obsahových vedomostí alebo didaktických zručností (Brom et al., 2020). Hlbšia analýza našich dát i zahraničné zdroje ukazujú, že pocit kompetentnosti súvisí s vlastným vzdelaním rodiča. Podla dát z Holandska okolo 75 \% rodičov s vyšším vzdelaním, ale iba 40 \% rodičov s nižším vzdelaním sa cítilo kompetentne alebo maximálne kompetentne pomáhat' svojim det’om s úlohami (Bol, 2020).

Obavy, že deti doma nezískajú dostatočné vedomosti a rozvoj uviedlo približne $30 \%$ rodičov v našom výskume, pričom takmer žiadne alebo žiadne obavy nemalo 49 \% respondentov. Pre porovnanie podla štúdie z Írska 39-40 \% rodičov malo vel'ké až vel'mi vel'ké obavy, zatial' čo 25-31 \% rodičov nepocit'ovalo žiadne, alebo len malé obavy z domáceho vzdelávania (Doyle, 2020). Takmer $30 \%$ rodičov v našom výskume tiež uviedlo, že pocitovali vel'ký, až vel'mi vel'ký tlak pri zastupovaní učitel'ov v domácom vzdelávaní. 
Rodičia detí so ŠVVP pocitovali o niečo väčší tlak v porovnaní s rodičmi bežných detí, no tento rozdiel nebol štatisticky významný. Vyššiu mieru tlaku u rodičov detí so špeciálnymi potrebami počas pandémie si v štúdii vo Vel'kej Británii vysvetlujú prerušením stereotypu, prerušením podporných sietí dietatáa a náhlou zmenou rodiča na nevyškoleného učitel'a žiaka s potrebou špecifického prístupu (Asbury et al., 2020). Jednou z príčin vyššieho pocitovaného tlaku môže byt' tiež znížená dostupnost' odbornej podpory spôsobená napríklad aj uzatvorením poradenských centier v rámci epidemiologických opatrení. Ďalším možným faktorom zvyšujúcim subjektívne pocit’ovanú mieru tlaku u rodičov detí so ŠVVP je menšia prispôsobivost' týchto detí na nečakané situácie a narušenie ich každodennej rutiny, riziko výskytu častých zmien nálad a správania (Asbury et al., 2020; Lee, 2020; Toseeb et al., 2020). V miere prežívaných obáv v súvislosti s domácim vzdelávaním, ani v pocite kompetentnosti, sa rodičia detí so ŠVVP nelíšili od rodičov detí bez špeciálnych potrieb. Vo všeobecnosti však tí rodičia, ktorí sa cítili byt' menej kompetentní pri vzdelávaní svojich detí doma, mali tendenciu intenzívnejšie prežívat' obavy, že ich diet’a doma nezíska dostatočné vedomosti a intenzívnejšie pocitovali psychický tlak pri zastupovaní učitelov v domácom vzdelávaní počas koronavírus pandémie. Na nedostatok učitel'ských schopností a obsahových vedomostí na zastupovanie učitelov poukázala aj štúdia s vyše 9000 rodičmi z Českej republiky (Brom et al., 2020). Podobné úskalia uvádza aj štúdia z Pol'ska, kde sa rodičia cítili menej kompetentní a zodpovednost' za vzdelávanie doma presahovala ich možnosti (Parczewska, 2020).

Ďalej nás zaujímali aj odpovede rodičov na otvorenú otázku, z čoho majú obavy počas tohto náročného obdobia vo vztahu k učivu, škole a známkam a aké obavy vyjadrujú ich deti. Najčastejšie, približne v $20 \%$, sa odpovede rodičov týkali obáv zo zvládnutia školských povinností a nedostatku učiva, no často sa rodičia obávali aj negatívnych dopadov na zdravie či osobnost' detí, nedostatku osobných zručností zastúpit’ rolu učitela, komunikácie so školou, či sociálnej izolácie. Tieto obavy boli približne rovnako zastúpené aj u rodičov detí so ŠVVP, no v tejto skupine rodičov sme častejšie zaznamenali aj obavy súvisiace s financiami a organizáciou domácnosti; a prirodzene aj obavy spojené s absenciou podpory odborníkov, špecialistov. Obavy detí, či už s, alebo bez ŠVVP, sa podla výpovede rodičov najčastejšie týkali absencie sociálnych kontaktov a zvládania školských povinností. 
V skupine detí so ŠVVP sa častejšie vyskytujú problémy so spôsobom výučby počas koronavírusových opatrení a problémy spojené s vyučujúcimi a so školou, so vzájomnou komunikáciou, či dostupnostou výukových materiálov. Dôležitou správou však je, že pribl. tretina rodičov v oboch skupinách uviedla, že ich deti nemajú žiadne obavy. Pre porovnanie, podla štúdie mapujúcej obavy rodičov detí so špeciálnymi výchovno-vzdelávacími potrebami a zdravotným postihnutím v Anglicku pocitovali rodičia týchto detí obavy najmä zo zmien nálad a správania $\mathrm{v}$ dôsledku straty stereotypu a istoty ich detí (Asbury et al., 2020). Rovnako sa ich obavy dotýkali viac psychického stavu ich detí, finančných strát a strát v podporných sietach, ktoré mali vytvorené. Deti so špeciálnymi potrebami majú do svojho výchovno-vzdelávacieho procesu zahrnutých mnoho odborníkov, inštitúcií a ich vzdelávacie štandardy sú v maximálnej miere prispôsobené špeciálnym výchovno-vzdelávacím potrebám a rozvojovým možnostiam každého jedného diet’ata. Tento dočasný a vo vel'kej rýchlosti vzniknutý systém online vzdelávania nebol aplikovatel'ný na všetky ich potreby, čo mohlo vo väčšej miere zvýšit' tlak vyvíjaný na rodičov týchto detí.

Viac ako $12 \%$ rodičov v našom výskume uviedlo, že sa učitelia nepodielajú na učebnej činnosti ich detí a 37 \% rodičov hovorí o čiastočnej participácii učitel'ov na učebnej činnosti v domácom prostredí. Rodičia detí so ŠVVP sa v tomto ohlade nelíšili od rodičov bežných detí. Vo Vel'kej Británii prieskum rodičov s det'mi so špeciálnymi potrebami poukázal na nedostatočnú participáciu školy v prvých týždňoch opatrení a teda aj zvýšenú potrebu rodiča vytvorit' si podrobný plán starostlivosti a vzdelávania diet'at'a, ktorý by nahrádzal školskú rutinu (Asbury et al., 2020). Na Slovensku by pocit'ovanie nedostatočnej participácie učitelov a školy mohlo byt' vysvetlené malým množstvom škôl s fungujúcou elektronickou a komunikačnou platformou a tiež nedostatkom skúseností ako škôl, tak aj učitelov, s takouto online komunikáciou, čo naznačuje aj prieskum KPMG Business Institute (2020), kedy jedna pätina slovenských učitel'ov mala z tejto formy vyučovania obavy a najväčším problémom učitelov boli najmä technické problémy a nedostatok vhodných učebných materiálov. V Anglicku prieskumy poukazujú na variabilitu participácie školy na učebnej činnosti žiaka podla možnosti pripojenia na online vzdelávacie platformy (Cullinane, 2020).

Aj rodičmi vnímané nedostatky zo strany škôl počas pandémie koronavírusu sa týkali najmä chýbajúceho, či nedostatočného online vyučovania, s tým 
súvisiaceho nedostatočného vysvetlenia učiva, a tiež zlej organizácie zo strany školy a nejednotnosti v prístupe učitel'ov. Takmer pätina rodičov bola s prístupom školy spokojná a žiadne nedostatky nenašla. Podiel spokojných bol však v skupine rodičov detí so ŠVVP nižší. Častejšie, ako ostatní rodičia, sa st’ažovali na málo informácií a zlú komunikáciu, či nadmernú zát’až rodičov. Nepripravenost' škôl na dištančnú formu vyučovania sa odzrkadlila aj $\mathrm{v}$ tom, čo rodičia označovali ako najväčšiu potrebu v súvislosti so vzdelávaním doma počas pandémie. Dominantnou odpoved'ou pre obe skupiny bola potreba online vyučovania a vysvetlenia učiva. Menej často rodičia vyslovili potrebu väčšieho záujmu, a podpory učitelov, ale privítali by aj menej úloh a zadaní a viac času, ktorý môžu venovat' vzdelávaniu svojich detí.

V skupine rodičov detí so ŠVVP sa častejšie vyskytla tiež potreba lepšej komunikácie školy, možnosti konzultácie a v neposlednom rade aj potreba podpory odborníka, logopéda, špeciálneho pedagóga, a psychológa. Toto je jedným z problémov, na ktorý upozorňovala aj organizácia UNESCO Bangkok (2020), kde v krízových situáciách nie je rodičom detí so ŠVVP k dispozícii dostatočné množstvo vyškoleného personálu.

K najčastejšie identifikovaným potrebám rodičov z nášho výskumu patrí najmä technické vybavenie ako tlačiareň, notebook, internet a pod., učebnice a pracovné listy, ale aj video a audio výukové materiály. Česká školní inspekce (2020) vo svojom prieskume uvádza, že viac ako 90 \% žiakov na stredných školách má zabezpečené technické vybavenie, najmenej technicky vybavení žiaci boli na prvom stupni základných škôl - menej než 85 \% žiakov. Samozrejme sú významné rozdiely z hladiska krajov v Českej republike. Komplikácie s technickým vybavením sa taktiež ukázali v mnohodetných rodinách.

Čo sa týka materiálno-technického zabezpečenia, vel'ká čast' rodičov z výskumnej vzorky (40 \%) je vybavených adekvátne potrebám, no tento podiel klesá v prípade rodičov detí so ŠVVP. Rozdiel medzi skupinou rodičov detí bez identifikovaných špeciálnych potrieb a rodičov detí so ŠVVP môže byt' vysvetlený najmä potrebou špeciálnych kompenzačných pomôcok pre deti so ŠVVP, medzi ktoré patrí aj didaktická technika vrátane informačných a komunikačných technológií, modifikovaný počítač a iné upravené nástroje a pomôcky podla potreby žiaka, ktoré bývajú aj finančne nákladné a nemusia byt' prístupné takýmto det’om doma (Interný metodický materiál ŠŠI, 2012). 


\subsection{Limity výskumu}

Považujeme za dôležité poukázat’ aj na limity výskumu, ktoré je potrebné brat’ do úvahy pri interpretácii výsledkov. Príležitostný výber výskumnej vzorky nezabezpečuje jej reprezentatívnost', čo sa odzrkadlilo vo vysokom zastúpení žien a vysokoškolsky vzdelaných respondentov, či v nevyváženosti výskumných podskupín. Vzhladom na spôsob zberu dát je tiež možné predpokladat', že súčast’ou našej vzorky boli najmä rodičia s vysokým záujmom o výchovu a vzdelávanie svojich detí, čo je takisto potrebné zohladnit'. Za nedostatok nášho výskumu považujeme tiež skutočnost', že položky dotazníka, ktorých výsledky sú analyzované v predkladanej práci, neboli pilotne overované, čo súvisí najmä s ambíciou autorov rýchlo reagovat' na vzniknutú pandemickú situáciu.

\section{Záver}

Uzatvorenie vzdelávacích inštitúcii ako dôležité opatrenie proti šíreniu ochorenia spôsobeného vírusom covid-19 nám prinieslo celosvetovo skúsenost' s dištančným vzdelávaním pre všetky deti. Online výuka na Slovensku nám ukázala, ako rýchlo dokážeme reagovat' na vzniknutú situáciu a prispôsobit’ sa jej. V predkladanom výskume nám dáta poukázali ako vzdelávanie v súčasnosti a učebné materiály nedokážu reagovat' na rozmanitost' potrieb a záujmov detí, žiakov a študentov v školách. Niektoré skupiny detí sú z rôznych dôvodov zo vzdelávania vylučované, napríklad deti z problematických domácností, žiaci bez prístupu na internet, viac detí v domácnosti s jedným počítačom. S t'ažkost'ami sa tiež môžu stretávat' aj deti so špeciálnymi výchovno vzdelávacími potrebami. Mnohé z nich zostali bez podpory svojej školy a poskytovania kontinuálneho vzdelávania. Dáta poukázali, že rodičia týchto detí venovali viac času plánovaniu výuky doma a deti so ŠVVP, najmä na stredných školách, venovali učeniu denne viac času. Počas online výuky im chýbala najmä pomoc a podpora v podobe učitelov, ale aj špecialistov. Pri týchto det’och vidíme, že domáce podmienky nie sú zatial' nastavené na rozvíjanie zručností, ktoré deti so špeciálnymi výchovno-vzdelávacími potrebami potrebujú bez zvýšenej zát'aže ich rodičov. Záleží tiež na vlastnom vzdelaní rodiča a pocite kompetentnosti pomáhat' detom s výukou doma. Celková miera tlaku na všetkých rodičov sa pohybovala na hladine priemernosti, tretina rodičov skôr pocituje tlak pri takejto forme vzdelávania. Budúcnost' ukáže, či by sa dištančné vzdelávanie mohlo stat' permanentnou súčastou vyučovacieho procesu na Slovensku, avšak až potom, ked' sa odstránia jeho 
nedostatky v podobe nedostatočného materiálneho zabezpečenia, prispôsobia sa mu učebné materiály a forma výuky bude brat' do úvahy aj potreby detí so špeciálnymi výchovno-vzdelávacími potrebami.

\section{Literatúra}

Asbury, K., Fox, L., Deniz, E., Code, A., \& Toseeb, U. (2020). How is Covid-19 affecting the mental health of children with special educational needs and disabilities and their families? Cit. 21. máj 2020. Dostupné z https://doi.org/10.31234/osf.io/sevyd

Bol, T. (2020). Inequality in homeschooling during the Corona crisis in the Netherlands. First results from the LISS Panel. Cit. 16. máj 2020. Dostupné z https://www.uva.nl/en/shared-content/ faculteiten/en/faculteit-der-maatschappij-en-gedragswetenschappen/news/2020/04/ mapping-the-effects-of-homeschooling-on-social-inequality-in-educational-outcomes. html?cb

Brom, C., Lukavský, J., Greger, D., Hannemann, T., Straková, J., \& Švařríček, R. (2020). Mandatory home education during the covid-19 lockdown in the Czech Republic: A Rapid Survey of 1st9th Graders' Parents. Cit. 9. september 2020. Dostupné z https://psyarxiv.com/fbhn3

Burgess, S., \& Sievertsen, H. (2020). Schools, skills, and learning: The impact of Covid-19 on education. Cit. 16. máj 2020. Dostupné z https://voxeu.org/article/impact-covid-19education

Campbell, M.,A. (2020). An increasing risk of family violence during the Covid-19 pandemic: Strengthening community collaborations to save lives. Forensic Science International: Reports. Vol. 2. Dostupné z http://doi.org/10.1016/j.fsir.2020.100089

Carlson, L., Petts, R., \& Pepin, J. (2020). US couples' divisions of housework and childcare during Covid-19 pandemic. Cit. 13. máj 2020. Dostupné z https://doi.org/10.31235/osf.io/jy8fn

Cullinane, C. (2020). Covid-19 and home-schooling: The crisis has exacerbated and highlighted existing educational inequalities. Cit. 17. máj 2020. Dostupné z https://blogs.lse.ac.uk/ politicsandpolicy/home-schooling-covid-19/

Česká školní inspekce. (2020). Vzdělávání na dálku v základních a středních školách. Tematická zpráva. Praha: Česká školní inspekce. Dostupné z https://www.csicr.cz/getattachment/ b603bcaa-95d1-4587-8345-a4d88c138d9d/Tematicka-zprava-Vzdelavani-na-dalku-v-ZSa-SS? maxSideSize $=2000 \&$ width $=500$ \&height $=800$

Doyle, 0. (2020). Covid-19: Exacerbating educational inequalities? Cit. 21. máj 2020. Dostupné z http://publicpolicy.ie/papers/covid-19-exacerbating-educational-inequalities/

Interný metodický materiál ŠšI. (2012). Kompenzačné a špeciálne učebné pomôcky pre deti a žiakov so špeciálnymi výchovno-vzdelávacími potrebami. Bratislava, 2012. $52 \mathrm{~s}$. Dostupné z https://www.ssiba.sk/admin/fckeditor/editor/userfiles/file/Dokumenty/ KOMPENZACNE_POMOCKY.pdf

KPMG Business Institute. (2020). Online výuku znepríjemňujú našim učitelom najmä technické problémy. Cit. 22. máj 2020. Dostupné z https://home.kpmg/sk/sk/home/media/pressreleases/2020/04/online-vyuku-ucitelom-zneprijemnuju-technicke-problemy.html

Lades, L., Ladesab, L., Laffanc, K., Dalyd, M., \& Delaneyef, L. (2020). Daily emotional well-being during the Covid-19 pandemic. Cit. 14. máj 2020. Dostupné z https://psyarxiv.com/pg6bw/ 
Lavy, V. (2015). Do differences in schools' instruction time explain international achievement gaps? Evidence from developed and developing countries. Economic Journal, 125(588). Dostupné z https://doi.org/10.1111/ecoj.12233

Lee, J. (2020). Mental health effects of school closures during COVID-19. Cit. 11. september 2020. Dostupné z https://www.thelancet.com/journals/lanchi/article/PIIS23524642(20)30109-7/fulltext

Mangal, S. K., \& Mangal, S. (2013). Research methodology in behavioural sciences. Delhi: PHI Learning Private Limited.

MŠVVaŠ SR. (2020a). Indikatívna týždenná zátaž žiakov základných škôl pri dištančnom vzdelávaní. Dostupné z https://www.statpedu.sk/files/sk/aktuality/novinky-main/2020/ usmernenia-2020/tabulka-tyzdenna-zataz-ziakov.pdf

MŠVVaŠ SR. (2020b). Usmernenie $k$ obsahu a organizácii vzdelávania žiakov základných škôl počas mimoriadneho prerušenia školského vyučovania v školách v školskom roku 2019/2020. Dostupné $\mathrm{z}$ https://www.minedu.sk/usmernenie-k-obsahu-a-organizacii-vzdelavaniaziakov-zakladnych-skol-pocas-mimoriadneho-prerusenia-skolskeho-vyucovania/

Parczewska, T. (2020). Difficult situations and ways of coping with them in the experiences of parents homeschooling their children during the COVID-19 pandemic in Poland. Education 3-13.

Rafael, V., \& Krejčíková, K. (2020). eduRoma - Roma Education Project. Aký je rozdiel medzi „online“ a „offline“ žiakmi z chudobných rómskych komunít a čoho sa najviac obávajú po návrate do školy. Cit. 17. máj 2020. Dostupné z https://eduroma.sk/publikacie.html

Tomšik, R. (2017). Kvantitatívny výskum $v$ pedagogických vedách. Úvod do metodológie a štatistického spracovania. Nitra: PF, UKF.

Toseeb, U., Asbury, K., Code, A., Fox, L., \& Deniz, E. (2020). Supporting families with children with special educational needs and disabilities during Covid-19. Cit. 11. máj 2020. Dostupné z https://psyarxiv.com/tm69k/

UNESCO. (2020). COVID-19 impact on education. data. Cit. 19. máj 2020. Dostupné z https:// en.unesco.org/covid19/educationresponse

UNESCO Bangkok. (2020). Empowering students with disabilities during the COVID-19 crisis. Cit. 18. máj 2020. Dostupné z https://bangkok.unesco.org/content/empowering-studentsdisabilities-during-covid-19-crisis

Wang, G., Zhang, Y., Zhao, J., Zhang, J., \& Jiang, F. (2020). Mitigate the effects of home confinement on children during the COVID-19 outbreak. Dostupné z https://doi.org/10.1016/S01406736(20)30547-X

World Bank Group. (2020). How countries are using edtech (including online learning, radio, television, texting) to support access to remote learning during the COVID-19 pandemic. Cit. 21. máj 2020. Dostupné z https://www.worldbank.org/en/topic/edutech/brief/howcountries-are-using-edtech-to-support-remote-learning-during-the-covid-19-pandemic

Zákon č. 245/2008 Z. z. o výchove a vzdelávaní (školský zákon) a o zmene a doplnení niektorých zákonov. Dostupné z https://www.zakonypreludi.sk/zz/2008-245\#p54-10 


\section{Prílohy}

Príloha 1: Dotazník Edukácia našich detí počas koronavírus pandémie (Čast' 3).

\begin{tabular}{|c|c|c|}
\hline $\begin{array}{l}\text { Číslo } \\
\text { položky }\end{array}$ & $\begin{array}{l}\text { Dimenzia A: } \\
\text { Edukácia v rodinnom prostredí }\end{array}$ & Možnost' odpovede \\
\hline 1. & $\begin{array}{l}\text { Kol'ko hodín Vaše diet'a venuje povinnej } \\
\text { učebnej činnosti denne? }\end{array}$ & $\begin{array}{l}\text { Otvorená otázka (počet hodín). } \\
\text { Individuálne pre každé diet'a. }\end{array}$ \\
\hline \multirow[t]{3}{*}{2.} & $\begin{array}{l}\text { Plánujete vopred učebnú činnost' } \\
\text { diet'at’a? }\end{array}$ & A) Nie, skôr situačne \\
\hline & & B) Čiastočne \\
\hline & & C) Áno, vel'mi podrobne \\
\hline \multirow[t]{3}{*}{3.} & $\begin{array}{l}\text { Podiel'ajú sa učitelia Vášho/Vašich } \\
\text { diet'ata/detí na plánovaní učebnej } \\
\text { činnosti? }\end{array}$ & A) $\mathrm{Nie}$ \\
\hline & & B) Čiastočne \\
\hline & & C) Áno \\
\hline \multirow[t]{3}{*}{4.} & $\begin{array}{l}\text { Podiel'a sa Váš partner na povinnej } \\
\text { učebnej činnosti? }\end{array}$ & A) Nie \\
\hline & & B) Len málo \\
\hline & & $\begin{array}{l}\text { C) Vel'mi mi pomáha } \\
\text { D) Delíme túto činnost' v rovnakej miere }\end{array}$ \\
\hline 5. & $\begin{array}{l}\text { Kol'ko hodín denne Vy venujete učebnej } \\
\text { činnosti s Vašimi det'mi? }\end{array}$ & Otvorená otázka (počet hodín) \\
\hline \multirow[t]{3}{*}{6.} & $\begin{array}{l}\text { Máte dostatok materiálov a pomôcok } \\
\text { a vzdelávanie Vašich detí počas } \\
\text { koronavírus pandémie? }\end{array}$ & $\begin{array}{l}\text { A) Viac-menej nám chýbajú všetky } \\
\text { materiály a pomôcky }\end{array}$ \\
\hline & & $\begin{array}{l}\text { B) Chýbajú nám niektoré materiály } \\
\text { a pomôcky }\end{array}$ \\
\hline & & $\begin{array}{l}\text { C) Viac-menej máme zabezpečené } \\
\text { všetky potreby na vzdelávanie }\end{array}$ \\
\hline 7. & $\begin{array}{l}\text { Aké materiály, prostriedky alebo } \\
\text { pomôcky Vám chýbajú pri učebnej } \\
\text { činnosti Vašich detí počas koronavírus } \\
\text { pandémie? }\end{array}$ & Otvorená otázka \\
\hline $\begin{array}{l}\text { Číslo } \\
\text { položky }\end{array}$ & $\begin{array}{l}\text { Dimenzia B: Edukácia v rodinnom } \\
\text { prostredí - Obavy rodičov a detí }\end{array}$ & Možnost' odpovede \\
\hline 1. & $\begin{array}{l}\text { Necítim sa byt' dostatočne } \\
\text { kompetentný/á pri vzdelávaní môjho/ } \\
\text { mojich dietata'a/detí, ktorú musím robit' } \\
\text { počas koronavírus pandémie: }\end{array}$ & $\begin{array}{l}\text { Škála } 1-5 \text { (1 - rozhodne nesúhlasím až } \\
5 \text { - rozhodne súhlasím) }\end{array}$ \\
\hline
\end{tabular}




\begin{tabular}{|c|c|c|}
\hline 2. & $\begin{array}{l}\text { Mám obavy, že moje diet’a/ti doma } \\
\text { nezíska/jú dostatočné vedomosti } \\
\text { a rozvoj počas koronavírus pandémie. }\end{array}$ & $\begin{array}{l}\text { Škála } 1 \text {-5 (1 - rozhodne nesúhlasím } \\
\text { až } 5 \text { - rozhodne súhlasím) }\end{array}$ \\
\hline 3. & $\begin{array}{l}\text { Z čoho máte ešte obavy? (vo vzt'ahu } \\
\text { k učivu, škole, známkam, atd'.) }\end{array}$ & Otvorená otázka \\
\hline 4. & $\begin{array}{l}\text { Z čoho má/jú Vaše dieta/ti obavy počas } \\
\text { koronavírus pandémie? (vo vztahu } \\
\text { k učivu, škole, známkam, atd'.) }\end{array}$ & Otvorená otázka \\
\hline 5. & $\begin{array}{l}\text { Čo by Vám pomohlo pri vzdelávaní detí } \\
\text { doma počas koronavírus pandémie? }\end{array}$ & Otvorená otázka \\
\hline 6. & $\begin{array}{l}\text { Uved'te, v čom vidíte nedostatky zo } \\
\text { strany školy pri vzdelávaní detí počas } \\
\text { pandémie: }\end{array}$ & Otvorená otázka \\
\hline 7. & $\begin{array}{l}\text { Vymedzte na stupnici od } 1 \text { po } 5 \\
\text { (1 najmenší, } 5 \text { najväčší) vel'kost' tlaku, } \\
\text { ktorý pocitujete pri zastupovaní učitelov, } \\
\text { špecialistov starostlivosti o diet'a v rámci } \\
\text { bežného edukačného procesu Vášho } \\
\text { diet’at'a. }\end{array}$ & $\begin{array}{l}\text { Škála } 1-5 \text { (1 - rozhodne nesúhlasím } \\
\text { až } 5 \text { - rozhodne súhlasím) }\end{array}$ \\
\hline
\end{tabular}

\section{Autoři}

PaedDr. Robert Tomšik, PhD., Oddelenie diagnostických nástrojov, Výskumný ústav detskej psychológie a patopsychológie VÚDPaP, Cyprichova 42, 831 05, Bratislava, Slovensko, e-mail: robert.tomsik@vudpap.sk

Mgr. Eva Rajčániová, Oddelenie základného a aplikovaného výskumu, Výskumný ústav detskej psychológie a patopsychológie VÚDPaP, Cyprichova 42, 831 05, Bratislava, Slovensko, e-mail: eva.rajcaniova@vudpap.sk

PhDr. Petra Ferenčíková, Oddelenie diagnostických nástrojov, Výskumný ústav detskej psychológie a patopsychológie VÚDPaP, Cyprichova 42, 831 05, Bratislava, Slovensko, e-mail: petra.ferencikova@vudpap.sk

PhDr. Alena Kopányiová, PhD., Úsek výskumu a podpory VPaP, Výskumný ústav detskej psychológie a patopsychológie VÚDPaP, Cyprichova 42, 831 05, Bratislava, Slovensko, e-mail: alena.kopanyiova@vudpap.sk 


\title{
Parent's view on education during the covid-19 pandemic in Slovakia - comparison of parents of children with and without special needs
}

\begin{abstract}
The aim of the empirical study is to map the course of distance education in Slovakia during the covid-19 pandemic. Specifically, the research focuses on examining the differences in specifics of distance education between parents of children with special educational needs and parents of children with no identified special educational needs. Furthermore, the research aims to find out how parents and their children experience the provision of education in the home environment - their concerns and perceptions of provided school support. Using a purposely designed questionnaire, these variables were measured on a sample of 462 parents. The first part of the study is devoted to the theoretical background and current empirical knowledge that saturates research goals of the paper. The next section describes the methodological procedures. The last section of the work is devoted to interpretation of the results, in which the following findings are described in more detail: 2nd grade elementary school and high school students spend approximately one hour more studying per day compared to 1st grade elementary school students; parents who feel less competent to teach their children at home tend to worry more that their children will not acquire sufficient knowledge at home; the most common concerns of parents in relation to distance education relate to the mastery of their children's school responsibilities; the most common concerns of children are related to the absence of social contacts and fear of failing to meet school obligations. Differences in education planning, in perceived lack of teaching aids, or the need for specialist support were found between parents of children with and without special needs.
\end{abstract}

Keywords: covid-19, distance education, special educational needs 